Diachenko, A., Rusanova, O., Guo, P., Kong, X., Huang, Z., \& Guo, J. (2021). Characteristics of the Special Physical Fitness of Paddlers at a Distance of 200 m. Teoriâ ta Metodika Fizičnogo Vihovannâ, 21(1), 43-49. https://doi.org/10.17309/tmfv.2021.1.06

\title{
CHARACTERISTICS OF THE SPECIAL PHYSICAL FITNESS OF PADDLERS AT A DISTANCE OF 200 M
}

\author{
Andrii Diachenko ${ }^{1 \mathrm{ABCD}}$, Olga Rusanova ${ }^{2 \mathrm{AD}}$, Pengcheng Guo ${ }^{3 \mathrm{BC}}$, \\ Xianglin Kong ${ }^{4 \mathrm{BC}}$, Zijian Huang ${ }^{5 \mathrm{BC}}$, Jia Guo ${ }^{6 \mathrm{BC}}$ \\ 1,2,5,6 National University of Ukraine on Physical Education and Sport \\ ${ }^{3,4}$ Jiangxi Normal University \\ Authors' Contribution: A - Study design; B - Data collection; C - Statistical analysis; D - Manuscript Preparation; E - Funds Collection
}

Corresponding Author: Olga Rusanova, E-mail: rusanova2080@gmail.com

Accepted for Publication: March 20, 2021

Published: March 25, 2021

DOI: 10.17309/tmfv.2021.1.06

\begin{abstract}
The aim of the study. The overall goal of this manuscript was to gain a better understanding of differences in the level of functional support for special endurance for paddlers of uniform groups (in terms of sports qualification): men kayakers, men canoeists, and women kayakers who specialize in a distance of $200 \mathrm{~m}$.

Material and methods. 20 qualified paddlers' level of functionality is being assessed, among them are a group of elite athletes, the members of the Chinese national team and winners of the 2018 Asian Games.

Results. The important feature of the analysis is the evaluation of the structure of the ergonomic power of a 30-second maximum load. Estimating the average value of the ergometric power of work for 25-30 seconds of operation in accordance with the average power of the entire 30-second load made it possible to determine the ratio of the anaerobic alactic and lactic abilities of the athletes, taking into account the requirements of a 200-meter race for canoe and kayak paddlers.

A significant range of individual differences in the indices of reactive properties of the cardiorespiratory system, which are determined by the ratio of the partial pressure of $\mathrm{CO}_{2}$ and the maximum level of pulmonary ventilation $\left(\mathrm{V}_{\mathrm{E}} / \mathrm{PaCO}_{2}\right)$ during the 10 and 30 second test task, attracts attention.

The range of $\mathrm{V}_{\mathrm{E}} / \mathrm{PaCO}_{2}$ indicators was: the relation of partial pressure $\mathrm{CO}_{2}$ to pulmonary ventilation in the $10 \mathrm{~s}$ test $-2.3 \pm$ 0.8 for men kayakers; $2.3 \pm 0.7$ for men canoeists; $2.2 \pm 0.5$ for women kayakers; the relation of partial pressure $\mathrm{CO}_{2}$ to pulmonary ventilation in the $30 \mathrm{~s}$ test $-3.9 \pm 1.0$ for men kayakers; $3.8 \pm 1.1$ for men canoeists; $3.6 \pm 0.7$ for women kayakers. Conclusion. The results of the study indicate differences in the level of functional support for special endurance for paddlers of uniform groups (in terms of sports qualification): kayakers and canoeists who specialize in a distance of $200 \mathrm{~m}$.
\end{abstract}

Keywords: paddlers, aerobic energy supply, anaerobic energy supply, special performance.

\section{Introduction}

At present, there is no doubt that all athletes who have achieved high sports results have a high functional potential, which is characteristic for the kind of competition in canoe and kayak rowing (Kong et al., 2018; López-Plaza et al., 2019; Kong et al., 2020). In many respects, the functional potential of paddlers on canoes and kayaks is determined by the availability of high capacity energy supply systems (Tesch, 1983; Sheykhlouvand et al., 2018; Pickett et al., 2018; Paquette et al., 2018). The system for diagnosing the power of the energy

(C) Diachenko, A., Rusanova, O., Guo, P., Kong, X., Huang, Z., Guo, J., 2021. supply system for paddlers of high qualification at different distances is presented before (García-Pallarés et al., 2009; Guo et al., 2020; Diachenko et al., 2020).

Previous research has shown the predictive power of $\mathrm{V} \mathrm{O}_{2}$ max, maximal aerobic power (MAP), lactate threshold $\left(\mathrm{LT}_{2}\right)$, the energy cost of kayaking per unit distance for 1000, 500 and 200-m performance in Kayak athletes from national to international level (Fry \& Morton, 1991; Bishop et al. 2002; van Someren \& Howatson, 2008; Zamparo et al., 1999; Borges et al., 2015). In addition to a large contribution of the aerobic system, Kayak athletes, also benefit from higher anaerobic capacities. Indeed, Sprint Kayak intensities are typically contested above lactate threshold, showing that energy is also provided from non-oxidative sources. 
Elite level paddlers have a lactate threshold $\sim 80 \%$ $V \mathrm{O}_{2} \max$ and a high $V \mathrm{O}_{2}$ max. In addition, the contribution of the aerobic system to the energy production has been estimated as $\sim 37,65$ and $84 \%$ for 200, 500 and 1000-m respectively (Borges et al., 2015).

Moreover, several studies have shown that anaerobic capacities such as peak power, total work and peak lactate concentration in a 30-s "all-out" effort on kayak ergometer all have large-to-very large correlations with 200, 500 and 1000m on-water performance (van Someren \& Palmer, 2003; van Someren \& Howatson, 2008; Borges et al., 2015).

However, the relationship of other fitness variables such as the respiratory system reactance to the increase of metabolic acidosis parameters and 200 -m Sprint Kayak performance in well-trained athletes has yet to be explored (Borges et al., 2015).

The training practices require review, especially in the case of qualified paddlers, as this group may begin to specialise their training toward this new format (Dyachenko, 2007; Kong et al., 2019).

The aim of the study: gain a better understanding of differences in the level of functional support for special endurance for paddlers of uniform groups (in terms of sports qualification) for men-kayak, for men-canoe and for women-kayak that specialize in a distance of $200 \mathrm{~m}$.

\section{Material and methods}

\section{Subject}

Depending on the purpose of the research phase, the theoretical and experimental parts of the research were conducted at different training periods at the national aquatic sports training centers in Beihai, Zhizhao (PRC). 20 qualified paddlers are in the process of assessing the level of functionality, among them a group of elite athletes, the members of the Chinese national team and winners of the 2018 Asian Games.

\section{Research protocol}

Physical Characteristics, Gas exchange, HR, and blood lactate measurements.

Minute ventilation $\left(\mathrm{V}_{\mathrm{E}}^{\cdot}\right)$, oxygen consumption $\left(\mathrm{V}^{\cdot} \mathrm{O}_{2}\right)$, $\mathrm{CO}_{2}$ production $\left(\mathrm{V}^{\cdot} \mathrm{CO}_{2}\right)$, were determined on a breath-bybreath basis using an Oxycon mobile (Jaeger) metabolimeter. The metabolic unit was calibrated a gas of known composition $\left(16.00 \% \mathrm{O}_{2}, 4.00 \% \mathrm{CO}_{2}\right)$, respectively.

HR was recorded every $5 \mathrm{~s}$ with an HR monitor ( $\mathrm{S} 610$ Polar Electro, Kempele, Finland).

The blood lactate concentration ([La]b) was determined using a portable lactate analyzer (Biosen S. line lab + ) on a blood sample obtained from the ear lobe at the end of the test.

A modified kayak-ergometer (Dansprint PRO, Denmark) was used. Ergometric power (EP) of work were recorded.

All the sportsmens performed an incremental exercise test on separate days, with at least 24 hours and no longer than 3 days between.

Depending on the purpose of the research phase, the theoretical and experimental parts of the research were conducted at different training periods at the national aquatic sports training centers in Beihai, Zhizhao (PRC).

The testing program is built in the form of test battery, each test solving a task to assess certain component of anaerobic abilities of athletes and cardiorespiratory system response. Test tasks were performed in a strictly determined sequence. It was important to preserve the parameters of the ergometric power of work which provided for the energy release in anaerobic alactate and anaerobic lactate (glycolytic) way, as well as the length of the rest intervals. The rest interval between $30 \mathrm{~s}$ and $90 \mathrm{~s}$ and work with maximum intensity provided the conditions for the release of lactic acid into the blood and the increase of the concentration of blood lactate in the muscles before the final maximum work.

Table 1 presents the control system and the content of test tasks to determine the quantitative characteristics of the main components of functional support of sprint paddlers.

Table 1. Characteristics of the indicators of functional support for special endurance of paddlers at a distance of $200 \mathrm{~m}$

\begin{tabular}{|c|c|c|}
\hline Indicators & $\begin{array}{l}\text { Test or period of indicator } \\
\text { measurement }\end{array}$ & Characteristics of the indicators \\
\hline Training impulse, TI, c.u. & Standard work, $6 \mathrm{~min}$ & The degree of intensity of functional support of work \\
\hline Watts mean $10 \mathrm{~s}$ & Test $10 \mathrm{~s}$, maximum work & $\begin{array}{l}\text { Paddlers' work release during the realization of anaerobic alactate } \\
\text { energy supply }\end{array}$ \\
\hline Watts mean $30 \mathrm{~s}$ & & $\begin{array}{l}\text { Paddlers' work release during the realization of the power of anaerobic } \\
\text { lactate (glycolitic) energy supply }\end{array}$ \\
\hline Watts mean $25-30 \mathrm{~s}$ & Test $30 \mathrm{~s}$, maxımum work & $\begin{array}{l}\text { Work release during the peak period of the power of anaerobic lactate } \\
\text { (glycolitic) energy supply }\end{array}$ \\
\hline Watts mean $90 \mathrm{~s}$ & Test $90 \mathrm{~s}$, maximum work & $\begin{array}{l}\text { Paddlers' work release during the realization of the capacity of anaerobic } \\
\text { energy supply }\end{array}$ \\
\hline Lactate, $\mathrm{mmol} \cdot \mathrm{l}^{-1}$ & after the test task & $\begin{array}{l}\text { Integral physiological characteristics of power and capacity of anaerobic } \\
\text { energy supply }\end{array}$ \\
\hline $\mathrm{V}_{\mathrm{E}} / \mathrm{PaCO}_{2}$ & $\begin{array}{l}\text { Test } 10 \mathrm{~s} \text {, maximum work } \\
\text { Test } 30 \mathrm{~s} \text {, maximum work }\end{array}$ & Respiratory system reactance to the increase of metabolic acidosis \\
\hline $\mathrm{VO}_{2} \max , \mathrm{ml} \cdot \mathrm{min}^{-1} \cdot \mathrm{kg}^{-1}$ & Test $90 \mathrm{~s}$, maximum work & $\begin{array}{l}\text { The Paddlers' ability to reach maximal aerobic power under conditions } \\
\text { of training and competitive loads of sprinting type }\end{array}$ \\
\hline HR Restoration to $120 \mathrm{bps}^{-1}$ & $\begin{array}{l}\text { During 3-5 minutes of restoration } \\
\text { period after the last test task }\end{array}$ & The degree of intensity of functional support of work \\
\hline
\end{tabular}


The testing program was built in the form of test battery, each test solving a certain task. Test tasks were performed in a strictly determined sequence.

It was important to preserve the individual maximum parameters of the ergometric power of work and the length of the rest intervals. The rest interval between 10 and $30 \mathrm{~s}$ work was one minute, between $30 \mathrm{~s}$ and $90 \mathrm{~s}$ work - five minutes. This provided for a full recovery and diagnostics of the structure of the reaction of anaerobic energy supply of sprint paddlers - anaerobic alactate and lactate (glycolytic) power, anaerobic capacity. The test program also created the conditions for the display of the cardiorespiratory system reactive properties and the power of aerobic energy supply for the work.

It is noteworthy that in the assessment system presented in the table there are no indices of the degree of stress of the cardiorespiratory system of the body in the process of work the parameters of the training impulse and the rate of recovery of the organism. This is due to the fact that the evaluation criteria are of an individual character and are considered in the dynamics for each particular athlete. They indicate the state of the athlete's body in the process of monitoring their functional abilities.

The research related to human use has complied with al the relevant national regulations and institutional policies; has followed the tenets of the Helsinki Declaration, and has been approved by the authors' institutional review board or al equivalent committee. Informed consent has been obtained from all individuals included in this study.

\section{Statistical Analysis}

The following methods of mathematical statistics were applied: descriptive statistics, selective method, ShapiroWilk's normality test, non-parametric Mann-Whitney test. Methods of descriptive analysis were used, including tabular presentation of separate variables, calculation of mean arithmetic value (M), standard deviation (SD). The sample data for normality were tested with the normal distribution formula and the Shapiro-Wilks test. The level of $p$ $\leq 0.05$ (the probability of error) was assumed statistically significant.

\section{Results}

The indicators of the functional abilities of sprint paddlers, presented in Table 2 characterize high (unique) requirements for the level of development of specific aspects of functional support for special performance efficiency of paddlers at a distance of $200 \mathrm{~m}$. This is indicated by the average values of the indices of paddlers from a homogeneous group, as well as by the data characterizing the functional abilities of sprint paddlers who have the highest sport results in the international arena. These data are systematized as a result of long-term observations of the leading athletes of China.

The range of the three highest indicators was:

- aerobic power $\left(\mathrm{VO}_{2} \max \right)$ in the range of 68.3$70.1 \mathrm{ml} \cdot \mathrm{min}^{-1} \cdot \mathrm{kg}^{-1}$ for men; $66.0-68.4 \mathrm{ml} \cdot \mathrm{min}^{-1} \cdot \mathrm{kg}^{-1}$ for women;

- maximum lactate concentration in blood (La max) - 20.5-22.0 mmol. $\mathrm{l}^{-1}$ for men, $17.5-19.1 \mathrm{mmol} \cdot \mathrm{l}^{-1}$ for women;
Table 2. Specific indicators of the functional abilities of highly qualified paddlers specializing in a distance of $200 \mathrm{~m}$ $(\mathrm{n}=20), \mathrm{p}<0.05$

\begin{tabular}{|c|c|c|c|}
\hline Indicators & $\begin{array}{c}\text { Values of } \\
\text { indicators } \\
(\mathrm{M} \pm \mathrm{SD})\end{array}$ & $\begin{array}{l}\text { The highest } \\
\text { values of } \\
\text { indicators }\end{array}$ & $\begin{array}{c}\text { Reduced } \\
\text { values of } \\
\text { indicators }^{\star *}\end{array}$ \\
\hline \multicolumn{4}{|c|}{ Values of indicators for men - kayak } \\
\hline$\overline{\mathrm{VO}_{2} \max , \mathrm{ml} \cdot \mathrm{min}^{-1} \cdot \mathrm{kg}^{-1}}$ & $65.1 \pm 2.6$ & 65.1 & 56.9 \\
\hline $\mathrm{V}_{\mathrm{E}} / \mathrm{PaCO}_{2} 10 \mathrm{~s}$ & $2.3 \pm 0.8$ & 3.2 & 1.3 \\
\hline $\mathrm{V}_{\mathrm{E}} / \mathrm{PaCO}_{2} 30 \mathrm{~s}$ & $3.9 \pm 1.0$ & 5.1 & 2.5 \\
\hline La max, mmol. $\cdot 1^{-1}$ & $18.0 \pm 1.2$ & 21.2 & 14.7 \\
\hline W10 s, Watt & $555.8 \pm 9.5$ & 570.0 & 527.0 \\
\hline W30 s, Watt & $495.0 \pm 10.2$ & 512.0 & 460.0 \\
\hline $\begin{array}{l}\text { W25-30 s - } 30 \text { s of test, } \\
\text { Watt }\end{array}$ & $525.2 \pm 9.0$ & 542.0 & 475.0 \\
\hline W90, Watt & $278.3 \pm 13.1$ & 295.0 & 256.0 \\
\hline \multicolumn{4}{|c|}{ Values of indicators for men - canoe } \\
\hline $\mathrm{VO}_{2} \max , \mathrm{ml} \cdot \min ^{-1} \cdot \mathrm{kg}^{-1}$ & $65.5 \pm 2.4$ & 65.5 & 55.3 \\
\hline $\mathrm{V}_{\mathrm{E}} / \mathrm{PaCO}_{2} 10 \mathrm{~s}$ & $2.3 \pm 0.7$ & 3.3 & 1.4 \\
\hline $\mathrm{V}_{\mathrm{E}} / \mathrm{PaCO}_{2} 30 \mathrm{~s}$ & $3.8 \pm 1.1$ & 5.2 & 2.9 \\
\hline La max, mmol. $\cdot 1^{-1}$ & $17.3 \pm 1.0$ & 20.9 & 16.2 \\
\hline W10 s, Watt & $460.1 \pm 6.9$ & 480.0 & 454.0 \\
\hline W30 s, Watt & $425.6 \pm 14.3$ & 443.0 & 405.0 \\
\hline $\begin{array}{l}\text { W25-30 s - } 30 \text { s of test, } \\
\text { Watt }\end{array}$ & $441.1 \pm 9.0$ & 466.0 & 425.0 \\
\hline W90, Watt & $269.0 \pm 10.0$ & 290.0 & 246.0 \\
\hline \multicolumn{4}{|c|}{ Values of indicators for women - kayak } \\
\hline$\overline{\mathrm{VO}_{2} \mathrm{ma}_{\mathrm{x}}, \mathrm{ml} \cdot \mathrm{min}^{-1} \cdot \mathrm{kg}^{-1}}$ & $60.4 \pm 2.7$ & 61.2 & 50.3 \\
\hline $\mathrm{V}_{\mathrm{E}} / \mathrm{PaCO}_{2} 10 \mathrm{~s}$ & $2.2 \pm 0.5$ & 3.0 & 1.4 \\
\hline $\mathrm{V}_{\mathrm{E}} / \mathrm{PaCO}_{2} 30 \mathrm{~s}$ & $3.6 \pm 0.7$ & 4.6 & 2.4 \\
\hline La max, mmol. $\cdot 1^{-1}$ & $16.9 \pm 1.2$ & 19.0 & 11.2 \\
\hline W10 s, Watt & $325.5 \pm 3.0$ & 333.0 & 303.0 \\
\hline W30 s, Watt & $300.5 \pm 9.0$ & 321 & 266 \\
\hline $\begin{array}{l}\text { W25-30 s - } 30 \text { s of test, } \\
\text { Watt }\end{array}$ & $315.5 \pm 7.9$ & 327.0 & 290 \\
\hline W90, Watt & $177.5 \pm 6.1$ & 191.0 & 155.0 \\
\hline
\end{tabular}

Note. ${ }^{*}$ - the indicators of the most successful athletes on the domestic and international arena; ${ }^{* *}$ - indicators of the least successful athletes in the group of athletes

- average energy power of the work during $10 \mathrm{~s}$ test 580.0-610.0 Watts for men- kayak, 470.0-490.0 Watts for men - canoe, 330.0-345.0 Watts for women;

- average energy power of the work during $30 \mathrm{~s}$ test for men-kayak 505.0-535.0 Watts, 430.0-450.0 Watts for men-canoe, 305.0-320.0 Watts for women;

- average energy power of the work during 25-30 s of 30 s test for men-kayak 530.0-540.0 Watts, 445.0-455.0 Watts for men-canoe, 320.0-330.0 Watts for women;

- average energy power of the work during $90 \mathrm{~s}$ maximal test for men-kayak - 380.0-400.0 Watts, 390.0-415.0 Watts for men-canoe, for women (60 s test) - 280.0300.0 Watts.

The range of $\mathrm{V}_{\mathrm{E}} / \mathrm{PaCO}_{2}$ indicators was:

- the relation of partial pressure $\mathrm{CO}_{2}$ to pulmonary ventilation in $10 \mathrm{~s}$ test $-2.3 \pm 0.8$ for men-kayak; $2.3 \pm 0.7$ for men-canoe; $2.2 \pm 0.5$ for women-kayak; 
- the relation of partial pressure $\mathrm{CO}_{2}$ to pulmonary ventilation in $30 \mathrm{~s}$ test $-3.9 \pm 1.0$ for men-kayak; $3.8 \pm 1.1$ for men-canoe; $3.6 \pm 0.7$ for women-kayak.

The data presented in the table indicate that the group is homogeneous. This is evident from the low individual differences in the indices of the power supply system and the performance efficiency of the paddlers. At the same time, a significant range of individual differences in the indices of reactive properties of the cardiorespiratory system, which are determined by the ratio of the partial pressure of $\mathrm{CO}_{2}$ and the maximum level of pulmonary ventilation $\left(\mathrm{V}_{\mathrm{E}} / \mathrm{PaCO}_{2}\right)$ during 10 and 30 second test task, attracts attention.

Analysis of individual paddlers' data has established a trend in which the highest level of performance of sprinter paddlers is displayed under the condition of high response of the cardiorespiratory system. In this case, we are talking about the initial "neural" part of the reaction (in the test of 10 seconds) and the respiration reaction on the increase in metabolic acidosis during the 30 -second test task. It is important to note that the characteristics of $\mathrm{CO}_{2}$ emissions $\left(\mathrm{VCO}_{2}\right.$, $\left.1 \cdot \mathrm{min}^{-1}\right)$ in the group of athletes did not differ significantly. The range of individual differences $(\mathrm{CV})$ of $\mathrm{VCO}_{2}$ was in the range of $6.3-6.7 \%$ for all categories of paddlers.

Analysis of the individual data of the five paddlers who had high scores $(x>M)$ and five paddlers who had reduced scored $(\mathrm{x}<\mathrm{M})$ for performance as a result of execution of all the test tasks showed the differences in the performance of the paddlers, and the differences in physiological reactivity of the organism to the specific loads of sprinter paddlers.

They are presented on the basis of assessment of the performance and reactivity of the respiratory system of leading sprinter paddlers, prize-winners and participants in the finals of the world championships and the Olympic Games.

The analysis also showed that a decrease in the reactivity of the respiratory system to the growth of acidic shifts is a factor in reducing the possibility of realizing individual indices of aerobic and anaerobic power of energy reactions.

This is evident from the ratio of the indices of $\mathrm{PaCO}_{2}$, $\mathrm{VO}_{2} \max$ (under special diagnostic conditions of $\mathrm{VO}_{2} \max$ ) and the highest $\mathrm{VO}_{2}$ value reached in the testing of the function of the sprinter paddlers $\left(\mathrm{VO}_{2} \max _{\text {sprinttest }}\right)$. The results of testing the paddlers, which had a ratio of $\mathrm{VO}_{2} \max _{\text {sprinttest }} / \mathrm{VO}_{2}$ max at high - 90\% and higher, reduced $-80.0 \%$ and lower than the indicator level, were being analyzed.

It is interesting to note that most of the leading athletes (6 out of 7) had higher levels of lactate concentration in special test tasks for sprinter paddlers. The level of lactate concentration in the seventh athlete as a result of the application of test tasks for the registration of $\mathrm{VO}_{2}$ max and when performing the sprint test program was practically the same. A distinctive feature of the reaction of the organism of these athletes was a higher respiration rate on $10 \mathrm{~s}$ and $30 \mathrm{~s}$ of the load compared to the group of paddlers $(n=8)$, who had lower performance indicators. Differences were up to $41-52 \%$ in the test of $10 \mathrm{~s}$ and $49-63 \%$ in the test of $30 \mathrm{~s}$.

An important feature of the analysis was the comparison of the ergometric power performance in 30 seconds and in the period of 25-30 seconds of execution. Athletes with a high level of functional preparedness, had all the performance characteristics presented at a pronounced high level. This indicated a balanced character of the manifestation of anaerobic alactate and anaerobic lactate capacity in the overall energy balance of execution.

\section{Discussion}

The Kayak program at the Olympic Games has changed with the inclusion of the 200-m events for both men and women. Up to and including the 2008 Beijing Olympics, male Sprint Kayak athletes had competed over 500 and 1000$\mathrm{m}$ races and women over $500 \mathrm{~m}$ only. However, at the 2012 games the 200-m for men and women was included at the expense of the men's 500-m program. Due to the larger difference in raced distances in the new program, male athletes were required to focus their training and specialize in either the $200-\mathrm{m}$ or $1000-\mathrm{m}$ event and to date, little is known if women can focus on both the 200-m and 500-m. However, there is presently relatively little available empirical data on the race profiles and physiological demands of these events to inform coaches and scientists to develop evidence-based training programs for young developing athletes to compete in these events (Hagner-Derengowska et al., 2014; Kong et al., 2019). At the elite level, the men's individual Sprint Kayak race durations are approximately 35 and $204 \mathrm{~s}$ for the 200 and $1000-\mathrm{m}$, respectively. Further, for women's the $200-\mathrm{m}$ lasts 39 to $40 \mathrm{~s}$ and K1 $500 \mathrm{~m}$ performances range from 107 to $120 \mathrm{~s}$ for the winners. Additionally, men and women also have crew competitions with faster performances in $\mathrm{K} 2$ and $\mathrm{K} 4$ crafts for all these distances (200, 500 and 1000-m). It Sprint Kayak is an Olympic sport that requires the athletes to compete over 200-m ( 35 s), 500-m ( 110 s) and 1000-m $(\sim 215 \mathrm{~s})$ in individual, double and four-seat boats (Bishop, 2004; van Someren \& Howatson, 2008; Borges et al., 2015).

Well-trained Kayak athletes complete maximal 200-m time trials $\sim 36.9-43.1 \mathrm{~s}$, maintaining a mean power output of $\sim 546 \mathrm{~W}$, with an accumulated oxygen deficit of $\sim 48.8 \mathrm{ml} \mathrm{O} 2$ Eq.kg-1. Conversely, 1000-m time trials last $\sim 216-248 \mathrm{~s}$ with a mean power and accumulated oxygen deficit of $\sim 226 \pm 30$ $\mathrm{W}$ and an $\sim 31.0 \mathrm{ml} \mathrm{O}$ Eq. $\mathrm{kg}^{-1}$, respectively (van Someren \& Palmer, 2003; Borges et al., 2015). These findings suggest elite Kayak athletes require specialised training programs, which vary in effort duration and effort to help optimally prepare them for specific race distances. However, at present there is a poor understanding of the appropriate training sessions that meet the demands of each of Kayak racing.

Sprint Kayak athletes have presented scores for absolute $\mathrm{VO}_{2}$ max of $3.9 \pm 0.7(2.9-5.0) \mathrm{L} \cdot \mathrm{min}^{-1}$ and relative $56.9 \pm$ 8.5 (44.6-68.6) $\mathrm{mL} \cdot \mathrm{kg}^{-1} \cdot \mathrm{min}^{-1}$ (Bishop et al., 2002, Garcia-Pallares et al., 2010; Borges et al., 2015). Unfortunately, accurate comparison between studies is difficult as various exercise protocols, exercise modes and equipment have been used to measure these capacities. Nonetheless, based on current evidence, it seems that Sprint Kayak athletes would benefit from a well-developed aerobic system as the longer races are contested close to $\mathrm{VO}_{2} \max$ (Jones \& Burnley, 2009; Bishop, 2004).

Many authors have shown that other aerobic characteristics, such as maximal power output at $\mathrm{VO}_{2}$ max level and anaerobic traits like power produced during $30 \mathrm{~s}$ and 2-min and the accumulated oxygen deficit (Bishop, 2004; van Someren \& Palmer, 2003, van Someren \& Howatson, 2008) relate to Sprint Kayak performance, highlighting the importance of developing both metabolic pathways for competitive success.

Reports from laboratory studies showed that, despite similar blood lactate responses $\left(\sim 9.6 \pm 1.6 \mathrm{mmol} \cdot \mathrm{L}^{-1}\right)$, the shorter duration events (30 s maximal efforts) have higher 
anaerobic oxygen deficit ( $29 \%$ higher) compared to $120 \mathrm{~s}$ maximal efforts (Bishop, 2004; van Someren \& Palmer, 2003).

The results van Someren and Palmer (2003) demonstrate that superior upper body dimensions and anaerobic capacities distinguish international-level kayakers from nationallevel athletes and may be used to predict 200-m performance.

A training program with either excessive or insufficient training load may impair the training-induced adaptations. In order to monitor the athletes, there is the need first to objectively quantify the training loads with proper and valid methods (Carter et al., 2000; Impellizzeri et al., 2005; Nicolas et al., 2006; Poole et al., 2008; Simoneau, 1998).

An important feature of the assessment of the effect of the above-mentioned physiological stimuli of reactions is that paddlers with high qualifications and at the same high level of humoral stimulation, the kinetics of the reaction are distinguished by the rates of deployment and recovery of the cardiorespiratory system and aerobic energy supply, their mobility under conditions of increasing fatigue (Nakazono \& Miyamoto, 1987; Miyamoto et al., 1987; Diachenko, 2004).

\section{Conclusion}

The important feature of the analysis is the evaluation of the structure of the ergonomic power of a 30-second maximum load. Estimating the average value of the ergometric power of work for 25-30 seconds of operation in accordance with the average power of the entire 30 -second load made it possible to determine the ratio of the anaerobic alactate and lactate abilities of the athletes, taking into account the requirements of a 200-meter race for canoe and kayak rowing.

A significant range of individual differences in the indices of reactive properties of the cardiorespiratory system, which are determined by the ratio of the partial pressure of $\mathrm{CO} 2$ and the maximum level of pulmonary ventilation (VE/ $\mathrm{PaCO} 2)$ during 10 and 30 second test task, attracts attention.

The range of $\mathrm{V}_{\mathrm{E}} / \mathrm{PaCO}_{2}$ indicators was:

- the relation of partial pressure $\mathrm{CO}_{2}$ to pulmonary ventilation in $10 \mathrm{~s}$ test $-2.3 \pm 0.8$ for men-kayak; $2.3 \pm 0.7$ for men-canoe; $2.2 \pm 0.5$ for women-kayak;

- the relation of partial pressure $\mathrm{CO}_{2}$ to pulmonary ventilation in $30 \mathrm{~s}$ test $-3.9 \pm 1.0$ for men-kayak; $3.8 \pm 1.1$ for men-canoe; $3.6 \pm 0.7$ for women-kayak.

Thus, the results of the studies indicate differences in the level of functional support for special endurance for paddlers of uniform groups (in terms of sports qualification) for kayaks and canoes that specialize in a distance of $200 \mathrm{~m}$.

\section{Conflict of Interest}

Authors declare no conflict of interest.

\section{References}

Kong Xianglin, Rusanova, O., Diachenko, A.,\& Kosticova, S. (2018). Description of functional support for special performance throughout the race distance of well-trained rowers in China. Journal of Physical Education and Sport, 18(4), 2324-2330. https://doi.org/10.7752/jpes.2018.04351

López-Plaza, D., Alacid, F., Rubio-Arias, J. Á., LópezMiñarro, P. Á., Muyor, J. M., \& Manonelles, P. (2019). Morphological and Physical Fitness Profile of Young
Female Sprint Kayakers. Journal of Strength and Conditioning Research, 33(7). https://doi.org/10.1519/jsc.0000000000002511

Kong Xianglin, Guo Pengcheng, Wang Weilong, Rusanova, O., \& Diachenko, A. (2020). Planning special physical training for rowers in China: a randomized study. Journal of Physical Education and Sport, 20(4), 1688-1694. https://doi.org/10.7752/jpes.2020.04229

Tesch, P. A. (1983). Physiological characteristics of elite kayak paddlers. Canadian journal of applied sport sciences. Journal canadien des sciences appliquees au sport, 8(2), 87-91.

Sheykhlouvand, M., Khalili, E., Gharaat, M., Arazi, H., Khalafi, M., \& Tarverdizadeh, B. (2018). Practical Model of LowVolume Paddling-Based Sprint Interval Training Improves Aerobic and Anaerobic Performances in Professional Female Canoe Polo Athletes. Journal of Strength and Conditioning Research, 32(8), 2375-2382. https://doi.org/10.1519/JSC.0000000000002152

Pickett, C. W., Nosaka, K., Zois, J., Hopkins, W. G., \& Blazevich, A. J. (2018). Maximal Upper-Body Strength and Oxygen Uptake Are Associated With Performance in HighLevel 200-m Sprint Kayakers. Journal of Strength and Conditioning Research, 32(11), 3186-3192. https://doi.org/10.1519/JSC.0000000000002398

Paquette, M., Bieuzen, F., \& Billaut, F. (2018). Muscle Oxygenation Rather Than VO2 max as a Strong Predictor of Performance in Sprint Canoe-Kayak. Int J Sports Physiol Perform., 19, 1-9.

García-Pallarés, J., Sánchez-Medina, L., Carrasco, L., Díaz, A., \& Izquierdo, M. (2009). Endurance and neuromuscular changes in world-class level kayakers during a periodized training cycle. European journal of applied physiology, 106(4), 629-638. https://doi.org/10.1007/s00421-009-1061-2

Guo Pengcheng, Kong Xianglin, Rusanova, O., Diachenko, A., \& Wang Weilong (2020). Functional support of the first part of competitive distance in cyclic sports with endurance ability: rowing materials. Journal of Physical Education and Sport, 20(5), Art 373, 2745-2750. https://doi.org/10.7752/jpes.2020.05373

Diachenko, A., Guo Pengcheng, Wang Weilong, Rusanova, O., Kong Xianglin, \& Shkrebtiy, Y. (2020). Characteristics of the power of aerobic energy supply for paddlers with high qualification in China. Journal of physical education and sport, 20(supplement issue 1), art 43, 312-317. https://doi.org/10.7752/jpes.2020.s1043

Fry, R. W., \& Morton, A. R. (1991). Physiological and kinanthropometric attributes of elite flatwater kayakists. Medicine and science in sports and exercise, 23(11), 1297-1301.

Bishop, D., Bonetti, D., \& Dawson, B. (2002). The influence of pacing strategy on $\mathrm{VO} 2$ and supramaximal kayak performance. Medicine and science in sports and exercise, 34(6), 1041-1047. https://doi.org/10.1097/00005768-200206000-00022

van Someren, K. A., \& Howatson, G. (2008). Prediction of flatwater kayaking performance. International journal of sports physiology and performance, 3(2), 207-218. https://doi.org/10.1123/ijspp.3.2.207

Zamparo, P., Capelli, C., \& Guerrini, G. (1999). Energetics of kayaking at submaximal and maximal speeds. European journal of applied physiology and occupational 
physiology, 80(6), 542-548.

https://doi.org/10.1007/s004210050632

Borges, T.O., Dascombe, B., Bullock, N., \& Coutts, A.J. (2015). Physiological characteristics of well-trained junior sprint kayak athletes. International Journal of Sports Physiology and Performance, 10(5), 593-599.

https://doi.org/10.1123/ijspp.2014-0292

Dyachenko, A.Y. (2007). The modern concept of improving the special endurance of high-class athletes in rowing. Science in Olympic sports, 1, 54-61.

Kong Xianglin, Guo Pengcheng, Rusanova, O., \& Diachenko, A. (2019). Reaction of the organism to repeated training loads, directed to improve the performance of the qualified rowers of China. Journal of Physical Education and Sport, 19(Supplement issue 2), 453-460. https://doi.org/10.7752/jpes.2019.s2066

van Someren, K. A., \& Palmer, G. S. (2003). Prediction of 200-m sprint kayaking performance. Canadian journal of applied physiology = Revue canadienne de physiologie appliquee, 28(4), 505-517. https://doi.org/10.1139/h03-039

Bishop, D. (2004). The validity of physiological variables to assess training intensity in kayak athletes. International journal of sports medicine, 25(1), 68-72. https://doi.org/10.1055/s-2003-45233

Hagner-Derengowska, M., Hagner, W., Zubrzycki, I., Krakowiak, H., \& Słomko, W., Dzierżanowski, M., Rakowski, A., Wiącek-Zubrzycka, M. (2014). Body structure and composition of canoeists and kayakers: analysis of junior and teenage polish national canoeing team. Biology of Sport, 31(4), 323-6.

https://doi.org/10.5604/20831862.1133937

García-Pallarés, J., García-Fernández, M., Sánchez-Medina, L., \& Izquierdo, M. (2010). Performance changes in world-class kayakers following two different training periodization models. European journal of applied physiology, 110(1), 99-107. https://doi.org/10.1007/s00421-010-1484-9

Impellizzeri, F. M., Rampinini, E., \& Marcora, S. M. (2005).

Physiological assessment of aerobic training in soccer. Journal of sports sciences, 23(6), 583-592. https://doi.org/10.1080/02640410400021278

Jones, A. M., \& Burnley, M. (2009). Oxygen uptake kinetics: an underappreciated determinant of exercise performance. International journal of sports physiology and performance, 4(4), 524-532. https://doi.org/10.1123/ijspp.4.4.524

Carter, H., Jones, A. M., Barstow, T. J., Burnley, M., Williams, C., \& Doust, J. H. (2000). Effect of endurance training on oxygen uptake kinetics during treadmill running. Journal of Applied Physiology, 89(5), 1744-1752. https://doi.org/10.1152/jappl.2000.89.5.1744

Nicolas J A Berger , Berger, N. J., Tolfrey, K., Williams, A. G., \& Jones, A. M. (2006). Influence of continuous and interval training on oxygen uptake on-kinetics. Medicine and science in sports and exercise, 38(3), 504-512. https://doi.org/10.1249/01.mss.0000191418.37709.81

Poole, D. C., Barstow, T. J., McDonough, P., \& Jones, A. M. (2008). Control of oxygen uptake during exercise. Medicine and science in sports and exercise, 40(3), 462-474.

https://doi.org/10.1249/MSS.0b013e31815ef29b

Simoneau, G.G. (1998). The impact of various anthropometric and flexibility measurements on the sit-and-reach test. Journal of Strength and Conditioning Research, 12(4), 232-237.

https://doi.org/10.1519/00124278-199811000-00005.

Nakazono, Y., \& Miyamoto, Y. (1987). Effect of hypoxia and hyperoxia on cardiorespiratory responses during exercise in man. Japanese journal of physiology, 37(3), 447-457. https://doi.org/10.2170/jjphysiol.37.447

Miyamoto, Y., Nakazono, Y., \& Yamakoshi, K. (1987). Neurogenic factors affecting ventilatory and circulatory responses to static and dynamic exercise in man. Japanese journal of physiology, 37(3), 435-446. https://doi.org/10.2170/jjphysiol.37.435

Dyachenko, A.Y. (2004). Special endurance of qualified athletes in rowing. NPF Slavutich-Dolphin. $338 \mathrm{p}$.

\title{
ХАРАКТЕРИСТИКИ ФУНКЦІОНАЛЬНОГО ЗАБЕЗПЕЧЕННЯ СПЕЦІАЛЬНОӤ ПРАЦЕЗДАТНОСТІ СПОРТСМЕНІВ, ЯКІ СПЕЦІАЛІЗУЮТЬСЯ НА ДИСТАНЦІї 200 м У ВЕСЛУВАННІ НА БАЙДАРКАХ І КАНОЕ
}

\author{
Андрій Дяченко ${ }^{1 \mathrm{ABCD}}$, Ольга Русанова ${ }^{2 \mathrm{AD}}$, Пенчен Го ${ }^{3 \mathrm{BC}}$, \\ Сянлінь Кун ${ }^{4 \mathrm{BC}}$, Цзицзянь Хуан ${ }^{5 \mathrm{BC}}$, Цзя Го \\ 1,2,5,6Національний університет фізичного виховання та спорту України \\ ${ }^{3,4}$ Педагогічний університет Дзянсі
}

Авторський вклад: А - дизайн дослідження; В - збір даних; C - статаналіз; D - підготовка рукопису; Е - збір коштів

Реферат. Стаття: 7 с., 2 табл., 30 джерел.

Мета дослідження - визначити відмінності у рівні функціонального забезпечення спеціальної працездатності веслувальників однорідних груп (за спортивною кваліфікацією) для чоловіків-байдарочників, чоловіків-каноїстів і жінок - байдарочниць, які спеціалізуються на дистанції 200 м у веслуванні на байдарках і каное.
Матеріали і методи. У досліджені брали участь 20 кваліфікованих веслувальників, серед яких елітні спортсмени, члени збірної команди Китаю та переможці Азіатських ігор 2018 року.

Результати. Важливою особливістю аналізу є оцінка структури ергометричної потужності 30-секундного мак- 
симального навантаження. Оцінка середнього значення ергометричної потужності роботи за 25-30 секунд роботи відповідно до середньої потужності всього 30-секундного навантаження дозволила визначити співвідношення анаеробних алактатних і лактатних спроможностей спортсменів 3 урахуванням вимог змагальної дистанції 200 м у веслуванні на байдарках і каное.

Заслуговує уваги діапазон індивідуальних відмінностей показників реактивних властивостей кардіореспіраторної системи, які визначаються співвідношенням парціального тиску $\mathrm{CO}_{2}$ і максимального рівня легеневої вентиляції $\left(\mathrm{V}_{\mathrm{E}} /\right.$ $\mathrm{PaCO}_{2}$ ), зареєстрованих під час виконання 10 і 30 секундних тестових завдань.
Діапазон показників $\mathrm{V}_{\mathrm{E}} / \mathrm{PaCO}_{2}$ становив: відношення парціального тиску $\mathrm{CO}_{2}$ та легеневої вентиляції за $10 \mathrm{c}$ $2,3 \pm 0,8$ для чоловіків-байдарочників; $2,3 \pm 0,7$ для чоловіків-каноїстів; 2,2 \pm 0,5 для жінок - байдарочниць; відношення парціального тиску $\mathrm{CO}_{2}$ та легеневої вентиляції за 30 с - 3,9 $\pm 1,0$ для чоловіків-байдарочників; $3,8 \pm 1,1$ для чоловіків-каноїстів; $3,6 \pm 0,7$ для жінок-байдарочниць.

Висновок. Результати досліджень вказують на відмінності в рівні функціонального забезпечення спеціальної працездатності веслувальників однорідних груп (за спортивною кваліфікацією) байдарочників і каноїстів, які спеціалізуються на дистанції 200 м.

Ключові слова: гребці, аеробне енергозабезпечення, анаеробне енергозабезпечення, спеціальні характеристики.

\section{Information about the authors:}

Diachenko Andrii: adnk@ukr.net; https://orcid.org/0000-0001-9781-3152; National University of Ukraine on Physical Education and Sport, Department of aquatic sports, Fizkultury St, 1, Kyiv, 03150, Ukraine.

Rusanova Olga: rusanova2080@gmail.com; https://orcid.org/0000-0001-7495-7030; National University of Ukraine on Physical Education and Sport, Department of aquatic sports, Fizkultury St, 1, Kyiv, 03150, Ukraine.

Guo Pengcheng: 87397161@qq.com; https://orcid.org/0000-0003-1019-7145; Jiangxi Normal University, Ziyangdadao St, 99, Nanchang City, China.

Kong Xianglin: 290892353@qq.com; https://orcid.org/0000-0001-7232-7713; Jiangxi Normal University, Ziyangdadao St, 99, Nanchang City, China.

Huang Zijian: chnhzj@163.com; https://orcid.org/0000-0002-6759-4953; National University of Ukraine on Physical Education and Sport, Department of aquatic sports, Fizkultury St, 1, Kyiv, 03150, Ukraine.

Guo Jia: gj710962948@gmail.com; https://orcid.org/0000-0001-6708-7049; National University of Ukraine on Physical Education and Sport, Department of aquatic sports, Fizkultury St, 1, Kyiv, 03150, Ukraine.

Cite this article as: Diachenko, A., Rusanova, O., Guo, P., Kong, X., Huang, Z., \& Guo, J. (2021). Characteristics of the Special Physical Fitness of Paddlers at a Distance of 200 m. Teoriâ ta Metodika Fizičnogo Vihovannâ, 21(1), 43-49. https://doi.org/10.17309/tmfv.2021.1.06

Received: 23.11.2020. Accepted: 20.03.2021. Published: 25.03.2021

This work is licensed under a Creative Commons Attribution 4.0 International License (http://creativecommons.org/licenses/by/4.0). 